\title{
The media and the military: Allies or adversaries?
}

\author{
DR LEOPOLD SCHOLTZ \\ Department of History, University of Stellenbosch
}

\section{Introduction}

Military commanders like Alexander the Great or Richard the Lionheart did not have to take public opinion greatly into account when they planned their campaigns in their day. Today it is a very different situation.

In the light of the above this article starts with two somewhat startling quotes by the futurologists Alvin and Heidi Toffler: "The people thinking hardest about warfare in the future know that some of the most important combat of tomorrow will take place on the media battlefield." They also state: "[T]he media, including channels and technologies unimagined today, will be a prime weapon for Third Wave combatants in both the wars and anti-wars of the future, a key component of knowledge strategy."2

In recent years, much has been made of the adversarial relations between journalists and the military. The media have, for instance, been blamed for the US defeat in Vietnam, for unthinkingly blabbing about tactical decisions in advance in the Falklands, etc. From their side, journalists have been blaming the military for not trying to understand the nature of their job, of covering up a number of bad things, etc.

It will probably have to be accepted that in modern, democratic countries there will always be a structural tension between the media and the military - and, for that matter, between the media and the whole government apparatus. All too frequently the media wants to open up, to uncover scandals, while the government apparatus, of which the military forms a part, wants publicity, but only on their terms. And then they get angry when the media doesn't want to play their game.

The relationship between the military and the media therefore has to be explored: are they allies or adversaries? This article shall firstly look at what the media and the military are respectively, and what makes them tick in terms of communication, propaganda and publicity. Thereafter a historical perspective will be given and the formal situation in the old and the new South Africa will be analysed, and lastly a modus vivendi whereby all role players should be able to live, will be explored.

1 Dr. Leopold Scholtz is senior deputy editor of Die Burger in Cape Town and visiting professor of history at the University of Stellenbosch. He also holds the rank of captain in the Reserve Force of the South African Army.

2 Alvin and Heidi Toffler: War and Anti-War, Survival at the Dawn of the 21st Century (London, 1994), pp. 216 and 230. 


\section{The media and the military}

In terms of the role of the media in modern societies an important point needs to be made from the outset. This is that the trend all over the world is towards greater openr:ss, more transparency and more communication. In fact, communication has prob.bly become one of the most important aspects of the modern world - so much so, that we can speak of a communications revolution. This revolution has two important elements: one involving people; the other regarding technology.

More or less until the sixties, the public in most democracies tended, by and large, to trust those in authority, to accept their word, to believe what was written in black and white, be it in newspapers or books and to accept as the truth what they saw on television. During the latter part of the sixties, with its climax in 1968, a revolution took place. Trust was elbowed out by distrust, uncritical acceptance was replaced by scepticism.

In growing measure, the public nowadays want those in leading positions to account for what they did or did not do; they want their leaders to explain to them and to convince them before they are willing to accept. In other words, communication - convincing communication, to be exact - has become ever more important to politicians who are dependent on a critical voters' corps for election or re-election. The average American, Danish, Australian or South African voter of today is a much tougher proposition than their ancestors of thirty plus years ago.

This is one of the reasons the floating vote has become much more important in most democracies. A few decades ago people largely voted according to class, ethnicity or tradition; today people to a far greater extent make either informed choices - or abstain from voting at all.

The reasons for this change are complex, but this article will look at one very important element, namely the technological revolution. The speed with which news and analyses can be dispatched around the world started to accelerate drastically at the end of the previous century because of the telegraph. When, for instance, an important battle took place, people would read about it in the newspapers within hours, instead of the weeks and months it previously took to inform people.

In the Vietnam War television was also introduced to the communication equation. The visual qualities of this medium were extremely powerful, and it played an ever more important role in defining the public's perceptions.

This process became faster and faster and today, in certain circumstances, real time access to the developments on the battlefield are available - vide $\mathrm{CNN}$ and the Gulf War. The Gulf War was, of course, a media war par excellence. One could see RAF Tornadoes taking off and returning from their first bombing missions over Iraq and hear pilots giving their first unedited, spontaneous views minutes after having been in action.

In a photo book about the Gulf War published by CNN, Thomas B. Allen, F. Clifton Berry and Norman Polmar sum it all up: "Television coverage of the Persian Gulf War changed the face of war. No longer can war be an event faraway in time and place. Television made war immediate. That is part of the story of the Persian Gulf War. Reporting on the war means reporting about television." 3 
Being in the employ of $\mathrm{CNN}$, the authors probably downplay the continued influence of the print media. But they nevertheless make a valid statement, the point of which is that dealing with the media and publicity in general has become an intrinsic part of soldiers' work, in peacetime and in war. No officer can think about strategy or operations any more without taking into account the media side. The fact that people are able to communicate almost instantly with each other via E-mail and the Internet, reinforces the point.

It also makes censorship much more difficult, and sometimes it will be downright impossible. An American officer, Colonel Alan Campen, says that commercial reconnaissance satellites will make it almost impossible for combatants to hide from the media, and with all sides watching the video screen, instant broadcasts from the battle zone threaten to alter the actual dynamics and strategies in war. It can, Campen says, "transform reporters from dispassionate observers to unwitting, even unwilling, but nonetheless direct participants" in a war. ${ }^{4}$

The point is, therefore, that people are to a greater or lesser extent informed better and faster than at any time previously, and that they demand independent sources for news-gathering and analysis of what it all means. This may vary from country to country; one may accept that - say - the Americans or Germans have traveled much further down this path than the Chinese or Congolese, but even in more authoritarian countries, the trend is basically the same. The fact is thus that the media both reflect and influence developments in society at large.

What modern audiences emphatically do not want, is one-sided propaganda, be it from the government, political parties or whomever - including the media. In modern societies there are enough newspapers and radio or television stations to switch to if you do not like the way a certain medium reports about what is happening in the world. Modern audiences are critical and want to be convinced, not fed with whatever somebody somewhere decides they should be fed with.

The reference is, therefore, to independent media, which refuses to take Big Brother's line (and Big Brother may, of course, either be the government, big business or some other powerful institution in society). The bottom line, in other words, is credibility. The media have to be credible in their presentation and analysis of the news, otherwise nobody would believe them either.

These two ideas, independence and credibility, are the bedrock of the discussion on the role of the media in a modern free society. This is important to keep in mind when we come to the relationship between the military and the media.

This is not to say that the media is untouchable, that they should not be accountable themselves. If the media sees itself as society's guardian against corruption, misuse of state authority, etc, who is guarding the guardian?

The media is run by journalists, and journalists are fallible people who make mistakes. There are good, professional and conscientious journalists who do their utmost; there are those who are only interested in sensation, who do not believe in having something as trite as the truth come between themselves and a good story. There are also journalists who try their best, but lack the expertise in a certain specialised field, such as medicine, or the military, and whose reports or articles are therefore below standard.

Toffler: War and Anti-War, p. 226. 
This is, obviously, of ongoing concern to all conscientious journalists in leading positions, who, therefore, try to rectify it. Being a newspaper editor, for example, to a large extent demands quality control: a job that never ends. The problem might never be solved, only ameliorated.

\section{The military}

In contrast to the media, the military can never be independent from government. If that were the case, it would be a very alarming development. According to the Prussian military thinker Carl von Clausewitz, war is essentially a political act: the grammar of war and politics may differ, he says, but not the intrinsic logic according to which they operate. ${ }^{5}$ This means that the government of the day is in the driving seat; it is the government who decides on policy, and it is the military who acts as a state instrument and implements policy in its own particular field.

Being a soldier means constant training for war, something the population fervently hopes will never materialise. This is the military's primary task. Their secondary task is to help the government with the maintenance of law and order. A task which, in the case of the SANDF, has become the primary focus in terms of exertion and time spent. Their tertiary task is to make their collateral capabilities available for disaster relief.

The tension with the modern media comes in two fields. Firstly, governments in general (and remember, the military forms part of the government structure) traditionally want publicity, lots of it, but only on their terms. They prefer the media to act as an uncritical trumpet of their successes; they prefer to be in the communications driving seat, and they become very irritated when the media refuse to bow to this. This was the case in the old South Africa and it is one of the things which hasn't changed all that much with the new government.

Secondly, in wartime, the military wants to restrict and control the flow of information about whatever is going on at the front, wherever that may be - in Lesotho or on the Cape Flats. Obviously, any soldier would understandably be very angry if a journalist would learn of, say, an attack or crime-prevention raid being planned for a certain place and time, and then publishing it as a juicy scoop in the next morning's edition, just in time for the enemy to learn about it and to take countermeasures.

A solution to this problem has to be found.

\section{Media and military in history}

Even in antiquity, kings used to take scribes along with them on campaigns in order to record their mighty deeds. Sometimes their accounts were the only ones surviving for modern historians to make sense out of; at other times separate accounts were discovered, placing events in a whole new light.

Newspapers first became fashionable in the sixteenth and seventeenth centuries. The first conflict to be extensively covered by independent newspapers, not as an extension of the war effort, was the American civil war. During the Boer War, British newspapers used to publish short telegrams by Lord Roberts or Lord Kitchener about battles and skirmishes in South Africa. Several weeks afterwards, war correspondents' accounts arriving by mail boat would then supplement the readers' understanding of what

5. Carl von Clausewitz: On War [Vom Kriege], III/6, p. 125. 
actually happened in much greater detail. These accounts were, by and large, objective, and are still very useful as sources by present-day historians. ${ }^{6}$

During the First World War, the speed of news transmitted to the home front became even greater. In this case, too, the press in general started fairly objectively, but were quickly bullied into submissiveness by their respective governments, who subjugated them by force of legal censorship into becoming mere propaganda outlets for the war effort. As British historian Niall Ferguson puts it: "Censorship probably did achieve something; the very fact that journalists complained so much about it speaks in its favour. It certainly kept a good deal secret ... The embarrassing loss of the battleship Audacious (sic) off Ireland in October 1914 was not reported in Britain, nor was the Battle of Jutland until some time after it was over. The Germans had no idea how serious the French mutinies of 1917 were; probably few French civilians did either." Nevertheless, Ferguson also comes to the conclusion (and here he supports the need for credibility) that "much of the vilification of the enemy and mythologising of the casus belli in which newspapers and other propagandists indulged was not seriously taken by those who fought; the efficacy of propaganda was in inverse relation to proximity to the Front. Only when based on the truth ... was propaganda effective in bolstering the will to fight." "7

By the start of World War II, the media was already an established presence on and around the battlefield. War correspondents, from the daily press and the makers of movie newsreels (the fore-runner of television), received army uniforms and were protected by the military, who also censored their accounts through specially appointed and trained censors.

In return, there was a tacit understanding that war correspondents would not give a negative picture of their own side's conduct or shoot the correctness of either the Allied or Axis war effort down. The war, right or wrong, was perceived by all sectors of society on both sides as a battle for survival, of good against evil, and the task of the war correspondent was to further that war effort, not make it more difficult by asking difficult questions or exposing malpractices. Of course, the German and Japanese media, being under strict state control, had no choice in the matter, while the Allied media theoretically did, but this did not matter very much in practice.

The Vietnam War was a watershed. This was a war, as the American strategist Harry G. Summers has noted, where the American government as a matter of policy did not try to solicit the support of its voters for what it first saw as a sort of policing action, and later because President Lyndon B. Johnson feared that kindling the passions of his people could work against his social reform policy. ${ }^{8}$

In other words, no effort was made to explain to the American people - and this included the media - why involvement in such a faraway war was vital or even important to American interests. Coupled to this the war was fought without a serious, cohesive understanding of the war aim. This filtered down to the media in Saigon, who were fed patent and transparent lies during the 'five o'clock follies', as the daily press conference at the US HQ in Saigon was derisively called by the journalists who were unfortunate enough to be there.

\footnotetext{
6 Here I am, of course, drawing on my own experience as a military historian who has written about the Anglo-Boer War and drawn on newspaper accounts as sources.

7 Niall Ferguson: The Pity of War (London, 1998), pp. 235 and 444.

8 Harry G. Summers: On Strategy II, a Critical Analysis of the Gulf War (New York, 1992), p. 9.
} 
Without this concerted effort, the media soon started to question, firstly the way in which the war was fought ("Either fight to win it, or get the hell out!"), and then the morality of the war as such. In the process a lot of journalists wrote dispatches which made the enemy in Hanoi very happy indeed. Because the war was fought in a totally cock-eyed manner, the reporters were caught up in a growing vortex, a belief that it was their task to 'expose' the immorality of the American involvement.

In later years, an American reporter, Robert Elegant, wrote that although the US and South Vietnam forces won almost every encounter against the Viet Cong and North Vietnamese Army on the battlefield, "the War was finally lost to the invaders after the US disengagement because the political pressures built up by the media had made it quite impossible for Washington to maintain even the minimal material and moral support that would have enabled the Saigon regime to continue effective resistance ... Despite their own numerous and grave faults, the South Vietnamese were, first and last, decisively defeated in Washington, New York, London and Paris. Those media defeats made inevitable their subsequent defeat on the battlefield." 9

As for the role of television, Dean Rusk, US foreign secretary in the Kennedy administration, had this to say: "This was the first struggle fought on television in everybody's living-room every day. What would have happened in World War II if Guadalcanal and the Anzio beach-head and the Battle of the Bulge or the Dieppe raid were on television and the other side was not doing the same thing? War is an obscene blot on the face of the human race. But whether ordinary people, who prefer peace to war in any country ... can sustain a war effort under that kind of daily hammering is a very large question."10

It is generally assumed that the so-called Tet Offensive at the beginning of 1968 was the turning point of the Vietnam War. Although the offensive was militarily decisively beaten back, and the Americans and South Vietnamese could boast of a great victory in anybody's language, the media portrayed it as a defeat. The reasons are partly because of reporters not well enough versed in military matters to make sense out of what was admittedly a very chaotic series of events, but mainly because the US government had maintained until then that the enemy was a spent force, that the US and South Vietnamese Army were sitting on top of things. Here it was demonstrated, at any rate during the first days of the offensive, that the enemy was not only very much alive and full of fight, but that it was able to take the initiative in a very spectacular way. ${ }^{11}$

There is another version. Harry G. Summers, for instance, does not doubt the role of the media in influencing public opinion to the extent that the US government's political room for maneuver was severely restricted. But, he says, the suspicion that the media was responsible for the loss of the war "is a dumb notion. While the media is good at showing the cost of war ... that cost only has meaning in relationship to the value of the war as determined by the objectives set by the government."

"Not media portrayals of the cost of the war, but the government's failure to establish those objectives, and hence fix the value of the war, was the primary cause for the lack of public support. In fact, although television was to claim that they had brought the horrors of war into the living room, post-war analysis of TV footage revealed that less p. 190 ,

10 Quoted in Michael Maclear: The Ten Thousand Day War (London, 1981), p. 296.

1 Cf. Keith William Nolan: The Battle for Saigon, Tet 1968 (New York, 1996), pp. 257-258. 
than three percent - seventy-six of twenty-three hundred stories from 1965 to 1970 contained scenes of heavy combat with dead or wounded shown on the screen."12

He also quotes the official US Army history of the war, which says: "Believing that the press had in most cases supported official policies in earlier American wars, especially World War II, many members of the military expected similar support in Vietnam. When the contradictions engendered by President Johnson's strategy of limited war led instead to a more critical attitude, the military tended increasingly to blame the press for the credibility problems they experienced, accusing television news in particular of turning the American public against the war." ${ }^{\prime 13}$ Note that the author primarily blames Johnson, not so much the press - who did, nevertheless, play a very important role.

In the Falklands War, the British realised the importance of whipping up public support for a war that was also very far away. They therefore took quite a lot of war correspondents along with the naval task force, and gave them every technical assistance to file their stories and articles.

In the beginning, the relations between the military and the media were decidedly frosty. In his memoirs, Rear-Admiral Sandy Woodward, commander of the British task force in the South Atlantic, relates how unsure he was dealing with "an unforeseen, though probably unwitting enemy, the Press". The guidelines he received from London for his dealings with the media, he says, could be summarized as "Co-operation, yes; information, no."

This shows that he and his bosses quite clearly did not understand how to deal with the media, and he proves the point by repeatedly castigating them (more often than not unconvincingly) for misquoting him. He even goes as far as to say that "the Press did not see itself as being on 'our' side at all. It saw itself as a fearless seeker after truth and I believe they found a considerable amount of it. The Argentinean Generals and Admirals admitted after the war that they gained ninety percent of all their intelligence about our activities from the British Press. The BBC World Service was particularly helpful."

Unfortunately Admiral Woodward omits to analyse the kind of intelligence the Argentineans purportedly gleaned from the media. If he had, he would probably have found that it related mainly to general news reports about the advance of the task force, the recapture of South Georgia, the air attacks on the Falklands, etc.

$\mathrm{He}$ then ameliorates his bias against the media by stating that "[w]e simply did not understand each other and the blame lay fairly equally". He says his side and the media "just operated on completely different mind-sets". A bit unfairly (but not too much) he says that "[t]heirs was a mixture of 'It doesn't matter much who wins or loses as long as we report it fairly and as, in our judgement, we see it.' There was also, on the editorial side, a bit of 'As long as we can sell it better than our competitors'. My mind-set was: 'Say and do whatever you have to win.' This is euphemistically worded these days as 'Be economical with the truth.' Hardly surprising, then, that we started so far apart."

It is, nevertheless, gratifying that he immediately follows this up: "And therefore amazing, perhaps, how quickly we all adjusted in the following few weeks. Perhaps this sort of attitude is another of those naval traditions we must make some compromises

\footnotetext{
12 Summers: On Strategy II, p. 224.

13 Ibid., pp. 224-225.
} 
on." 14 A prime example of the necessary adjustment to the information revolution of the late 20 th century.

The shoe in this war could, however, also be on the other foot. Martin Middlebrook writes about the 'confidential' leaks by the military to the media about the composition of the task force: "The Ministry of Defence deception operation was working well. A wellknown national newspaper published a list of ships believed to be with the task force; this contained all the ships actually in the force but also named seven others which were not!"15

In other words, false information was purposefully leaked to the media for dissemination to the enemy. In war, when all's fair, this is only to be expected. But then one should not actually blame the press for reporting the news.

Who actually got the better of the conflict between the media and the military in the Falklands, is an interesting question to ponder on. What is clear, is that both sides learnt fast.

Next on the list was the American invasion of Grenada, which became a media fiasco. In spite of this being the first fairly major operation being undertaken by the American military after the Vietnam War, journalists, even American ones, were almost totally barred from the scene. This soured military-media relations, which had just been on the mend, even further. This operation did, however, have the advantage of a major enquiry by the US military into its handling of the media, and a better understanding of how to do things. ${ }^{16}$

Things, therefore, went much better in the Gulf War, although the individual commanders still had to learn how to handle the media.

In his memoirs, General Norman Schwarzkopf recounts how he framed three rules for himself in his handling of journalists at the beginning of the conflict:

* “Don't let them intimidate you. You know a hell of a lot more about what's going on than they do."

* "There's no law that says you have to answer all their questions."

* "Don't answer any question that in your judgement would help the enemy."

But, he continues, "[s]uddenly it struck me that all three rules were negative in nature. 'Wait a minute, Schwarzkopf,' I thought, 'before you get carried away, think back to the lessons of the past. Think back to what caused the disenchantment of the American public with Vietnam: they felt that they were constantly being misled with false body counts and optimistic talk about the light at the end of the tunnel.' So I added rule number four, the most important of all: 'Don't ever lie to the American people.',

Schwarzkopf relates that he would truthfully say "I don't know" when this was the case. Most importantly, he goes on: "I also understood that any attempt to cover up bad news would lead to disaster." 17

\footnotetext{
14 Admiral Sandy Woodward: One Hundred Days, The Memoirs of the Falklands Battle Group Commander (London, 1992), pp. 112-113.

is Martin Middlebrook: Task Force: The Falklands War, 1982 (Middlesex, 1987), p. 74.

16 Summers: On Strategy II, p. 225.

17 General H. Norman Schwarzkopf: It Doesn't Take a Hero, the Autobiography (New York, 1993), p. 399.
} 
In other words, Schwarzkopf understood the need for truthfulness and transparency in the modern age - obviously without compromising tactical and operational surprise on the battlefield.

These words were echoed by Lieutenant-General Sir Peter de la Billière, commander of the British forces in the operational theatre. In his memoirs he described his approach thus: "Another urgent preoccupation of mine was with the media. In the Falklands I had learned to appreciate the power of the media and the influence they can exert, for good or ill. I had found, first, that if I could win reporters on to my side they could do a lot for the forces, and second, that if I put over a consistent message, that message would start to filter into the hearts and minds of people in the United Kingdom. Further, that message would permeate through to every level of British society, because if one influenced the people of Britain, one began to influence politicians as well - and support across the whole political spectrum was essential for the kind of major overseas operation which we were mounting."

"The media, in other words, were of crucial importance, especially with modern communications, which ensure that news is back in the United Kingdom almost before it has happened. It seemed to me vital that ... war should be reported properly and not from second-hand information; so in the Gulf I took a lot of trouble to bring the media alongside and gave them every possible facility." ${ }^{18}$

Which, of course, did not mean that everything went entirely smoothly. Reports that Brigadier Patrick Cordingley (later Major-General), commander of the 7th Armoured Brigade, the famed Desert Rats, had said at a press conference that the British public had to prepare themselves for a blood bath in the Gulf War led to a furore in the British Army, and threatened to sour relations with the media. ${ }^{19}$

This incident is dealt with in detail in General Cordingley's book about his experiences in the Gulf War. ${ }^{20}$ In hindsight, based on his account, it seems that the problem was due to a combination of some naïve remarks by Cordingley himself and one of his officers (probably because he did not understand the journalists' culture in a free society), and downright bad, sensasionalist reporting by certain individual reporters which were, therefore, wrongly followed up by other media. In fact, Cordingiey acknowledges that some reporters agreed in his presence that he had been badly treated.

All this, however, formed part of the learning curve and will, in the longer term, most probably be a positive experience.

Nevertheless, when the Kosovo War started, all the lessons, it seems, had been forgotten: Right from the beginning two problems plagued relations with the media. Firstly, that there was no co-ordination between press spokespersons at the Pentagon and at NATO headquarters in Brussels, with the result that differing and even conflicting pictures of the war were painted. Secondly, against the background of the politicians' gross miscalculation that president Slobodan Milosevic would cave in after two or three days of light bombardments, the spokespersons stayed very tight-lipped and gave out only the most basic information, and even then got some things patently wrong.

\footnotetext{
18 General Sir Peter de la Billière: Storm Command, a Personal Account of the Gulf War (London, 1992), pp. 63-64.

19 Brigadier Patrick Cordingley: In the Eye of the Storm, Commanding the Desert Rats in the Gulf War (London, 1996), pp. 112-118. 
As Jason DeParle of the New. York Times reported from Washington at the beginning of April 1999: "In briefings at the Pentagon and at NATO headquarters in Brussels, senior officials have refused to say exactly how many attack missions have been launched; how many of those missions have been completed despite the bad weather; how many bombs have been dropped; or what, precisely, the bombs have hit. Such statistical summaries were provided on a near-daily basis in the 1991 Persian Gulf War, even under an information policy then criticized by journalists as overly restrictive."

He also quotes former Marine, General Richard Neal, who conducted the daily briefings in Ryandh during the Gulf War, and is now a military analyst for CNN: "We're not getting anything from those folks. There's a concerted effort at withholding information, or maybe I shouldn't say withholding it - just not providing it." 21

The previous day, the New York Times editorialised: "When democracies send their military forces into combat, citizens need to know as much about the battles as sensible security precautions permit. In the case of Kosovo, with western reporters barred by Serbia from covering the conflict on the ground, NATO and the Pentagon must provide a detailed account of the effectiveness of the air war. It is a responsibility they have so far failed to meet ... In the weeks ahead, President Clinton may seek public support for escalating the air war ... Complicated political and security issues will have to be resolved before the conflict ends. It is essential that citizens have all the information they need to make informed judgments as these matters arise. Mr. Clinton and his counterparts in Europe do themselves and their countries a disservice by so tightly controlling information about the battle in Kosovo.",22

It is therefore gratifying that the criticising died down after a week or two. The media being what they are, frequently like to criticise, but when things start to go right, they are not as ready to give credit. Nevertheless, it seems that NATO finally got it right, and the fairly good relations between the media and the military were, therefore, restored.

\section{The South African situation}

In the old South Africa, things like democracy, political tolerance and press freedom were not the highest priority of the opposing role players on the political field. The drastic polarisation in the country meant that the quest for democracy in practice took a back seat to the contest for political power.

This was aided by a Westminster-type constitution according to which Parliament was sovereign. That meant that whoever formed the majority in the House of Assembly and after 1948 this was only the National Party - could, within the constraints of practicality in the short term, do exactly as they pleased. Given the cut-throat character of the contest for power, press freedom and freedom of speech was eroded to a large extent. This also permeated the relations between the military and the media.

According to the Defence Act of 1957 , as amended several times, the media was not allowed to report anything about the SADF which was not given out by the military themselves or expressly sanctioned by them. This did not merely apply to ongoing operations, but to everything. It gave the military carte blanche for the manipulation of news.

\footnotetext{
21 Jason DeParle: “Allies' progress remains unclear as few details are made public" (New York Times, 5 April 1999.
} 
In contrast to the American or British military, who were fully exposed to the social revolution regarding a sceptic public and the concomitant need for more communication and openness, the SADF was thus artificially shielded from a necessary experience, which meant that they were ill-equipped to withstand the relentless onslaught of the rapidly changing social-political context within which modern military forces have to operate and survive.

Thus, when South African forces were operating deep inside Angola during Operation SAVANNAH in 1975-76, the previous government - and the SADF - were lying through their teeth to the South African public by denying any South African involvement in the Angolan conflict. ${ }^{23}$

This was a scandalous breach of contract between the government and the voters who had entrusted it with power, and between the military and the people whom they were supposed to protect.

During all the cross-border operations which followed, from the attack on the SWAPO base at Cassinga in 1978 to the final phase in Angola in 1987-88, the South African public became ever more weary and sceptic of the strictly controlled and onesided information that came from official sources. Frequently the wildest rumours were bandied about.

Small wonder, then, that even government-supporting newspapers such as Die Burger protested against the counter-productive secrecy surrounding cross-border operations in Angola. As the newspaper wrote after the initial reports regarding South African involvement against the FPL offensive of 1987 (which evolved into Operation MODULÊR): "Dit maak nie sin dat buitelandse nuusmedia deur middel van vreemde nuus-agentskappe oorsee publisiteit gee aan ons betrokkenheid in Angola, terwyl die mense vir wie dit die belangrikste is - die ouers van die seuns wat daar veg en die publiek wat dit finansier en moreel steun - nie bevredigend deur hul eie plaaslike nuusmedia ingelig kan word nie."24

The government had its reasons for staying silent. It did not want to be seen to be involved in a war that was essentially a civil war in another country - perhaps understandable, but naïve in the extreme if one takes into account that an entire South African brigade was involved. But that also meant that the public support necessary to sustain a war effort was not sought, just as the American government neglected to do in Vietnam. The shortage of facts given out by the military in the name of security further meant that the enemy was able to win the propaganda war time and again. Propaganda and public relations have become, in the new world, essential parts of strategy and operations, and, therefore, of winning wars. As Harry G. Summers aptly writes, "To the degree that it jeopardises public support, total security may be worse than no security at all."25

In other words, the SADF tied their one hand, so to speak, behind their back to face an opponent who was able to use not only both hands, but his feet and teeth as well. What was made public, was perceived by a large segment of the South African public to be propaganda, and therefore untrustworthy. In contrast, the Cubans flew in reporters from

23 I myself was a student in the Netherlands at the time. While I was able to follow the campaign, and the South African role in it in detail through the international press, radio and television, my parents, family and friends back home were not only denied that information, but were shamelessly lied to.

Summers: On Strategy II, p. 227. 
several international news media to see for themselves what was going on. Importantly, they did not try to influence these reporters overtly; they let them report freely what they saw. But the reports were, of course, all from the Cuban side and about the Cuban perspective. ${ }^{26}$ By default then, the SADF and the government lost the information war hands down.

True, there were some relatively sophisticated attempts at media manipulation. A system of military correspondents for the various media was introduced, and the Conference of Editors, an informal grouping of newspaper editors, was sometimes briefed in confidence about what was going on. However, the flow of information was too strictly controlled. This meant that the media to a large extent lost their independence, and therefore also their credibility.

The disregard by the SADF and the old government for the growing importance of this aspect of strategy should be studied closely by the new SANDF, for it is a classic example of how to do things incorrectly. It is also important for the SANDF, as there are signs that the new government may slowly but surely be sliding down the same path.

This notwithstanding, the way in which the Defence Review was handled was very good. Right from the beginning it was an open and transparent process in which the public was continuously informed by way of media reports and public conferences. Even more importantly, all sectors of civil society were drawn into making contributions about how the country's defence should be structured. Even though the government and the SANDF in the end largely made its own decisions, this was a good example of how to do things.

\section{Operation BOLEAS}

Alas, the good work done with the Defence Review was to a great extent undone with the South African military intervention in Lesotho in September 1998. Seldom has there been a military operation where the communication and media liaison weaknesses of the South African government and military have been so cruelly exposed.

The purpose of this intervention, as explained by Interior Minister Mangosuthu Buthelezi - who, as acting president at the time, made the actual political decision - was "to quash a military coup which would have prevented the people of Lesotho from democratically resolving the conflict dividing the majority and its opposition". Elsewhere the minister stated that "[i]t was not the SADC's intention to interfere in the internal political and constitutional dynamics of Lesotho, but we intervened to ensure such dynamics could freely express themselves as the people of Lesotho best wish, without being silenced by the tyranny of a military coup. ${ }^{27}$ The mission the SANDF received from the government was "to intervene militarily in Lesotho to prevent any further anarchy and to create a stable environment for the restoration of law and order ...,28

This only came out well afterwards. From a public relation's point of view, the operation itself was a disaster, although strenuous attempts were later made by the SANDF to repair the damage. Things actually started going wrong at the national strategic level: the Government had no discernable consistent security policy for Southern Africa, lurching between the promotion of peace and support for military intervention 
elsewhere on the one hand, as well as between support for democratic governments and dictatorships alike on the other. This basic flaw brought about almost all the other troubles that beset BOLEAS from its inception.

As Lieutenant-General Deon Ferreira, Chief of Staff: Joint Operations, explained a few weeks afterwards to the Parliamentary Defence Committee and Portfolio Committee on Foreign Affairs, the absence of a clear national security policy meant that the decision to intervene in Lesotho thus came as a surprise to the SANDF itself as well. This meant that there was too little time to plan and prepare, which in its turn meant that there was no combat intelligence about how the mutineering soldiers of the Lesotho Defence Force would react, and therefore the initial intervention force of 600 men was far too small. More importantly, General Ferreira stated, there had been an absence of strategical guidelines for media liaison, which thus became reactive in nature. In fact, he says, communication - not media liaison - gave information to the media, which was not in accordance with the provisions of the Standard Operating Forces Agreement between South Africa and Botswana. His final conclusion was that the psychological and media war had been lost at all levels, especially the strategic level. ${ }^{29}$

Deputy Minister of Foreign Affairs Aziz Pahad admitted at the same briefing that the government's lack of a clear media strategy had fuelled criticism of the operation. He said few communications were issued during or immediately after the intervention and, as a result, the country was kept in the dark about the motives for and objectives of the operation. $^{30}$

Because of the inadequate time available, all effort went into operational planning of the operation itself. The SANDF's media liaison office was not included in the planning. Therefore, journalists woke up on the morning of Tuesday, 20 September 1998, just as ignorant and unprepared for the event as the rest of the South African and Lesotho population. Newsmen and -women rushed to the scene of the initial battles on their own, and negligible military effort was given to help the journalists on the ground with their task. Information such as was officially given out, came from DHQ in Pretoria. There were even instances of journalists coming under heavy fire from the LDF mutineers, and the SANDF refusing to bring them to safety. The officer in charge of communication of the operation, Major Ben van Zyl, merely said, according to news reports, that it was not the soldiers' duty to go and look for journalists "nadat ons aan hulle gesê het dis op hul eie verantwoordelikheid dat hulle Lesotho binnegaan nie".31

Now contrast this with the attitude expressed by commanders such as Admiral Woodward or General Schwarzkopf, and the full ineptness of the SANDFs media liaison during the first days of BOLEAS becomes clear. To be sure, after a few days this changed considerably. Journalists were flown in from South Africa and given full exposure to what was happening. Writing in Beeld, Sekola Sello stated: "Lede van die gesamentlike Suid-Afrika/ Botswana-mag soos lt.kol. Jorrie Jordaan en die oorhoofse bevelvoerder van die operasie, kol. Robbie Hartslief, was inderdaad baie behulpsaam teenoor die groot groep Suid-Afrikaanse en buitelandse mediamense in Lesotho ... dit [was] inderdaad ' $\mathrm{n}$ welkome en merkwaardige verandering om die Suid-Afrikaanse Leër so inskiklik te vind.",32

Ibid., pp. 30-38.

$30 \quad$ Sunday Independent, 8 Nov 1998.

$31 \quad$ Beeld, 24 Sep 1998.

32 Beeld, 4, 11 January 1998. 
The same must apply to the above-mentioned briefing General Ferreira gave to two parliamentary committees, in which he impressed journalists with his total honesty and transparency about what went wrong with the operation.

Which makes it all the more sad that the governing politicians could not bring themselves to a similar attempt at honesty. "Maar in die tipiese styl van Suid-Afrikaanse politici is dit diegene wat die slegte nuus gebring het" - in other words, the media - "wat tot skurk gemak word," writes Sello. ${ }^{33}$ At the same briefing where Ferreira appeared, Deputy Minister of Foreign Affairs, Aziz Pahad, called criticism of Boleas "bordering on treason or criminality", while his colleague of Defence, Ronnie Kasrils, even suggested that the media were actually lying when reporting that Maseru's central business district had been razed - and this when TV bulletin after TV bulletin showed a gutted and destructed city centre. ${ }^{34}$ Clearly a case of the messenger bearing the bad news being shot because the people in question take badly to media criticism.

All in all, from a media liaison point of view Operation BOLEAS did not go well at all. For this, the Government and its feeble attempts at damage control must bear the brunt of the responsibility. The SANDF itself began very badly as well, but ended up with considerable credit.

\section{Lessons}

Clausewitz wrote about the 'remarkable trinity' between the people, the army and the government. "The passions that are to be kindled in war," he wrote, "must already be inherent in the people ..." ${ }^{35}$ In other words, no war effort can be sustained for any period of time without the support of the people.

Why is this? Clausewitz also contends that "[s]ince war is controlled by its political object, the value of this object must determine the sacrifices to be made for it in magnitude and also in duration." ${ }^{36}$ In the past, the value of the political object, and therefore also the sacrifices, were determined by governments, and this is, of course, still the case to a great extent. But in a democratic and open society, where the government is accountable to the voters (who may reject it at the polling booth) and where the people follow the doings of their elected rulers critically, it is, in the final analysis, the people who have to be convinced that the value of the political object of the war is great enough for the expected sacrifices that the war might entail.

J.S. Kotze makes the point very explicitly: "Die openbare mening is bepalend vir die intensiteit waarmee nasionale belange beskerm moet word én die koste en die risiko's wat in dié verband aangegaan kan word. Militêre operasies wat nie openbare steun geniet nie, het dikwels rampspoedige politieke gevolge vir die regering en veroorsaak 'n groot verleentheid vir die gewapende magte."37

And for this, communication - stronger even, credible communication - is needed. The hard fact is that no government in a modern, democratic and open society is trusted enough any more to simply accept its word on face value. One of the biggest challenges facing any democratic government in the world today is, therefore, to get the media on its

Ibid.

Die Burger, 3 Nov 1998; Business Day, 3 November 1998.

Carl von Clausewitz: On War, $\mathrm{I} / 1$, p. 26.

Ibid., I/1, p. 11.

J.S. Kotze: "Die Strategiese Kontinuum: Raamwerk vir 'n Studie van Suid-Afrikaanse Strategie in die Namibiese Konflik" (Joernaal vir Eietydse Geskiedenis, 19/3, Desember 1994, pp. 44-45). 
side. For a news medium to be known to be manipulated by government (or anybody else) is to kill its credibility and therefore the efficacy of its message.

The experience of commanders in the Falklands, the Gulf, Kosovo and Lesotho related above attest to the fact that no strategist in a democratic society can reckon without the media any more. As also related above, the relationship can be a very prickly one, simply because the media has its own culture and way of doing things, and because the media is interested in opening things up, while a commander faced with an imminent operation might not want to disclose too much.

Nevertheless, the military and the media are, for better or for worse, condemned to each other, and they will simply have to learn to understand each other better, although they will never have an easy relationship as long as the press remain free.

As a media man, I would, therefore, like to end this paper by making some practical suggestions to both sides to ease the relations as much as possible:

* Make a point of studying the way the other side thinks and works. Expose yourself to their culture, or alternatively, appoint someone on your staff to do so - and then listen to his of her recommendations when they are made.

* Organize think tanks from time to time with representatives from both sides, where problems that may have arisen as well as the relations in general may be addressed. In this respect, the SANDF could do well to rethink its media liaison strategy. In the past, there was a system of military correspondents and even editors being confidentially informed about events. Although this, more often than not, was intended to manipulate the media, the basic idea remains a good one and could fruitfully be resuscitated.

* The media should ensure that at least one reporter on its staff has an adequate working knowledge of the military. Bad reporting happens too frequently because the reporter does not understand what he is dealing with.

* Dealing with the media and communications skills should become part and parcel of all officers' training courses. Officers should be made aware of the different levels of talking to the media - on the record, off the record and nonattributable - and they should learn how to mind their P's and Q's when speaking on the record. This applies not only to initial training courses, but also to staff courses, and even right at the top. Like everything else, dealing with the media in the new social and political circumstances doesn't come automatically; it has to be learnt.

* Officers should get to know their counterparts in the media and try to build a relationship of trust with them. They must open to them as far as is professionally possible, take them into their confidence. If the military does not want a story published yet, they will have to convince the media why this is so. That way, exceptions notwithstanding, the trust will mostly be reciprocated. Not always because of the high moral standard of the journalist, but because any good journalist knows that keeping confidences is in his own interest. Publishing information that was given with the understanding that it would be kept confidential is the surest way of never getting a good story ever again.

* The military must accept and respect the independence of the media. Respect the intelligence of (most of) the journalists. Experienced journalists have often developed antennae for smokescreens. Be truthful, do not try to mislead them. 
Once the media get the impression that this is what you are doing, they will tend to question even your truthful statements.

* The military should make a distinction between individual journalists. If one fails (and at one time or another, it probably will happen), it doesn't mean that all media people are bad. There are good and bad apples amongst the media, just as amongst soldiers.

* The military should accept the new information age as a given. It is counterproductive to resist it. Handling the media well has become an integral part of doing the job as a soldier well.

* In the final analysis, the military and the media should understand that while they are adversaries, they are also allies - albeit independent ones, each with their own agenda. Both should learn to handle this difficult relationship. 